\title{
How reliable are projections of future flood damage?
}

\author{
P. Bubeck ${ }^{1,2}$, H. de Moel ${ }^{1}$, L. M. Bouwer ${ }^{1}$, and J. C. J. H. Aerts ${ }^{1}$ \\ ${ }^{1}$ Institute for Environmental Studies, Faculty of Earth and Life Sciences, VU University Amsterdam, The Netherlands \\ ${ }^{2}$ German Research Centre for Geosciences GFZ, Helmholtz Centre Potsdam, Section Hydrology, Germany
}

Received: 24 May 2011 - Revised: 30 August 2011 - Accepted: 12 October 2011 - Published: 14 December 2011

\begin{abstract}
Flood damage modelling is an important component in flood risk management, and several studies have investigated the possible range of flood damage in the coming decades. Generally, flood damage assessments are still characterized by considerable uncertainties in stage-damage functions and methodological differences in estimating exposed asset values. The high variance that is commonly associated with absolute flood damage assessments is the reason for the present study that investigates the reliability of estimates of relative changes in the development of potential flood damage. While studies that estimate (relative) changes in flood damage over time usually address uncertainties resulting from different projections (e.g. land-use characteristics), the influence of different flood damage modelling approaches on estimates of relative changes in the development of flood damage is largely unknown. In this paper, we evaluate the reliability of estimates of relative changes in flood damage along the river Rhine between 1990 and 2030 in terms of different flood-damage modelling approaches. The results show that relative estimates of flood damage developments differ by a factor of 1.4. These variations, which result from the application of different modelling approaches, are considerably smaller than differences between the approaches in terms of absolute damage estimates (by a factor of 3.5 to 3.8), or than differences resulting from land-use projections (by a factor of 3 ). The differences that exist when estimating relative changes principally depend on the differences in damage functions. In order to improve the reliability of relative estimates of changes in the development of potential flood damage, future research should focus on reducing the uncertainties related to damage functions.
\end{abstract}

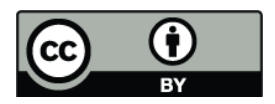

Correspondence to: P. Bubeck

(philip.bubeck@ivm.vu.nl)

\section{Introduction}

In recent years, flood management throughout Europe has gradually shifted from what are called "flood control approaches" to more integrated concepts, referred to as "flood risk management". While flood control approaches predominantly focused on preventing flood events with specific predefined return periods, flood risk management also takes into account the expected consequences of flooding such as direct economic losses or loss of life (Büchele et al., 2006; de Moel et al., 2009; Merz et al., 2010). Risk in this context is defined as "probability times damage", and thus describes the expected damage that can occur or will be exceeded with a certain probability in a certain period (e.g. Merz et al., 2010).

Following this shift to risk-based approaches, there has been an increasing interest in flood impact assessment and especially the estimation of direct economic losses (Dutta et al., 2003; Merz et al., 2004; Hall et al., 2005; PenningRowsell et al., 2005; Thieken et al., 2005; Bouwer et al., 2009; Luino et al., 2009; Kreibich et al., 2010). Knowledge of potential flood damage has a great importance for, inter alia, the identification of people and assets at risk, the planning and evaluation of effective flood mitigation and control measures, the creation of flood risk maps for awareness raising, and the calculation of flood insurance premiums (Messner et al., 2007; Merz et al., 2010). Furthermore, flood damage is projected to increase in the coming decades owing to on-going development in flood-prone areas and the projected effects of climate change on river discharges, and consequently flood probabilities (Middelkoop et al., 2001; IPCC, 2007; te Linde et al., 2010). Against this background, a growing number of studies have estimated the range of possible changes in the development of future flood damage in $\mathrm{Eu}-$ rope (Hall et al., 2005; Aerts et al., 2008; ABI, 2009; Feyen et al., 2009; Maaskant et al., 2009; Bouwer et al., 2010; te Linde et al., 2011).

Generally, flood damage assessments are still characterized by significant uncertainties associated with

Published by Copernicus Publications on behalf of the European Geosciences Union. 
stage-damage functions, as well as methodological differences in estimating the exposed asset values linked to these curves (Merz et al., 2004; Apel et al., 2008, 2009; Freni et al., 2010; Merz et al., 2010; de Moel and Aerts, 2011). While further efforts are currently being undertaken to reduce the uncertainties of flood loss assessment, it can be assumed that considerable uncertainty will remain in the coming years (Jonkman et al., 2008; Maaskant et al., 2009; Kreibich et al., 2010; Elmer et al., 2010). In order to better manage the large variations that are commonly associated with assessments of absolute flood damage, it is suggested that it would be useful to investigate the reliability of estimates of relative changes in the development of potential flood damage, especially in terms of the differences stemming from flood damage modelling approaches (de Moel and Aerts, 2011). Gaining insights into the reliability of relative estimates (as the percentage change of a reference situation) of flood damage in scenario studies is important, as these often form the basis of decision making and are used, for example, to evaluate the effectiveness of various risk reducing-strategies (ICPR, 2006; Aerts et al., 2008; ABI, 2009; Bouwer et al., 2010). The latter purpose is especially important because many investments in flood control and mitigation measures take 20 to $30 \mathrm{yr}$ to design, plan and implement and are also designed for long life spans (see e.g. Hallegatte, 2009; Dircke et al., 2010).

Furthermore, insights into the influence of different flood damage modelling approaches on relative estimates of flood damage developments are needed, given the increasing emphasis on basin-wide approaches for trans-boundary flood risk assessment. A basin-wide approach is currently required in Europe (EU, 2007) and facilitated by intergovernmental river basin organizations like the International Commission for the Protection of the Rhine (ICPR) or the International Commission for the Protection of the Danube River (ICPDR). In these organizations, the member countries need to jointly evaluate the effectiveness of various risk reducing-strategies over time (ICPR, 2006, 2007). However, different damage modelling approaches are applied by riparian countries (Meyer and Messner, 2005), and these can yield substantial differences in terms of absolute damage values (de Moel and Aerts, 2011), and the results are often difficult to compare. Therefore, usually one flood damage modelling approach needs to be chosen and agreed upon by the various stakeholders when conducting such joint assessments (ICPR, 2001a; Silva and Reuter, 2006). This makes it important to understand to what extent various damage modelling approaches used in different riparian countries or regions influence estimates of relative changes in flood damage developments. In order to improve such relative estimates, it is especially of interest to understand whether variations between the damage modelling approaches stem from the uncertainties in the damage curves or from differences in estimating the exposed asset values linked to these curves.
Studies that have evaluated the possible range of flood damage developments have commonly addressed the uncertainties originating from projections of socio-economic development and climate change by applying alternative scenarios for land-use change and flood probabilities linked to climate change (Hall et al., 2005; ABI, 2009; Bouwer et al., 2010). In addition, when focusing on the river Rhine in North-Western Europe, several scenario studies have evaluated the relative influence of climate and land-use change on flood damage developments (Klijn et al., 2007; Aerts et al., 2008; te Linde et al., 2011). However, it is largely unknown how different flood damage modelling approaches influence estimates of relative changes in the development of potential flood damage, as compared with those scenarios. This is because, although previous studies have applied a range of scenarios, they have generally only used one damage modelling approach to assess changes in flood damage.

The aim of the current study is, therefore, to evaluate the reliability of relative estimates of flood damage developments for the river Rhine with regard to different flood damage modelling approaches. We explain the differences for two damage models through simulating the effects of socioeconomic development, reflected by land-use scenarios, on flood damage between 1990 and 2030. These two damage models have been used earlier to assess potential flood damage in the Rhine Basin: the flood damage model used for the development of the Rhine Atlas (ICPR, 2001a) and the one called the "Damage Scanner" (Klijn et al., 2007). Furthermore, we will investigate whether variations in absolute and relative damage estimates between the approaches result from differences in damage functions or from the estimation of the exposed asset values. Finally, the variations stemming from the application of different flood damage modelling approaches are compared with the uncertainties originating from land-use projections.

The remainder of the article proceeds as follows: Sect. 2 provides a general introduction to flood damage modelling approaches. Section 3 describes the study area and discusses the data and methods applied in the present study. The results are presented and discussed in Sect. 4. Section 5 concludes.

\section{Flood damage assessments}

There is a wide range of approaches to estimate potential flood damage, mostly depending on the spatial and temporal scale of the analysis as well as on its purpose and the availability of data and resources (Messner et al., 2007). Microscale assessments are characterized by a high level of detail, and, from the exposure side, they usually take single objects into account that are at risk from flooding, such as buildings, vehicles or infrastructure. From the hazard side, consideration is given to location specific flood characteristics, such as flow velocity, water depth, or contamination of flood water. In meso-scale flood damage analyses, as applied in the 
present study, exposure information is usually based on the spatial aggregation of the exposed assets. Most commonly, meso-scale models combine information on land-use types for estimating assets at risk and information on inundation depth for simulating the hazard. On the macro-scale, even larger units, such as municipalities, regions or countries, are used for damage estimations (Merz et al., 2010).

A standard approach to quantify flood damage is the use of stage-damage functions (Smith, 1994; Merz et al., 2007). These can be developed using two different methodological approaches (Merz et al., 2010). First, empirical damage functions can be constructed on the basis of observed flood damage data. For example, the HOWAS database, which was maintained in Germany (Merz et al., 2004) and is now integrated in the HOWAS21 database ${ }^{1}$, is a collection of observed damage cases, and has provided the basis for the derivation of the damage functions applied in the Rhine Atlas (ICPR, 2001a). Second, stage-damage functions can be derived using synthetic approaches, which are based on expert judgement. Following this approach, experts from, for instance the insurance industry, estimate the damage that can be expected for different types of objects and assets when certain flood characteristics occur. The HIS-SSM damage model, which is the standard software in the Netherlands to evaluate flood damage (Kok et al., 2005), and the Multicoloured Manual in the UK (Penning-Rowsell et al., 2005) are both examples of this approach, although the HIS-SSM model also includes some empirical information. For more detailed overviews of flood damage assessment approaches and their various aspects, see Merz et al. (2010) and Messner et al. (2007).

\section{Study area, data, and methods}

Our research approach to study the reliability of estimates of relative changes in the development of potential flood damage is shown in Fig. 1. The river Rhine was chosen as a case study because it is the largest and economically most important river in Western Europe. Furthermore, the river basin is shared by nine countries, which need to engage in transboundary flood risk management and, being part of this, need to jointly evaluate the effectiveness of risk-reducing measures (ICPR, 2007). We apply two meso-scale flood damage models that have been commonly used for flood damage assessments along the Rhine: the Rhine Atlas model used by the ICPR (ICPR, 2001a), and what is called the "Damage Scanner" (Klijn et al., 2007). The two models have been selected because they show a large variability in absolute damage estimates (de Moel and Aerts, 2011), and have been derived using different methodological approaches. In both models, potential flood damage is quantified with the help of depth-damage functions that define for each land-use type

1 http://nadine-ws.gfz-potsdam.de:8080/howasPortal/client/ start the potential damage, depending on the given inundationdepth at the respective location. Other flood characteristics are not considered. The absolute flood damage estimates derived from applying the two models in the case study area are used to evaluate the relative change (in percentages) in flood damage owing to land-use change between 1990 and 2000, as well as between 2000 and the two land-use projections for 2030. Estimates of relative changes according to the two models are compared with each other in order to gain insights into the reliability of relative estimates of flood damage developments with regard to different flood damage modelling approaches. The remainder of this section describes the study area, the data, and the methods applied in the present study in greater detail.

\subsection{River Rhine basin}

The river Rhine originates in the Swiss Alps and flows through Austria, Switzerland, France and Germany into the Netherlands, where it eventually bifurcates into the North Sea and the Lake IJssel. The river basin area is about $197000 \mathrm{~km}^{2}$, and is shared by nine countries. The basin is densely populated, and, in total, about 58 million people live in the area (ICPR, 2001a, 2008). Especially since the 19th century, the Rhine has developed into an important traffic route and is today one of the world's most trafficked and used waterways. It connects one of the world's largest sea harbours in Rotterdam, the Netherlands, with the world's largest inland harbour in Duisburg and other industrial complexes in Germany, France, and Switzerland. Every year, about 200000 vessels cross the Dutch-German border, transporting approximately 200 million tons of goods (ICPR, 2008).

To aid shipping and industrialization, the main river channel has undergone substantial changes and has been rectified and canalized. From the original $8000 \mathrm{~km}^{2}$ of floodplains, less than 15 per cent remain (ICPR, 2008). Moreover, the canalization and rectification of the riverbed has caused an acceleration of flood wave propagation in the Rhine canal (Lammersen et al., 2002). These developments have led to an increasing risk of flooding, and the ICPR estimates that about 10 million people live at risk from extreme flooding (ICPR, 2001a). Flood protection levels, expressed as average return periods of peak discharges that can be withstood by dykes and embankments, vary along the river and range from $1 / 200$ per year in the Upper Rhine and parts of the middle Rhine, $1 / 500$ per year in the lower Rhine, to $1 / 1250$ and $1 / 2000$ per year in the Netherlands. Two major floods occurred in 1993 and 1995 along the Rhine that caused substantial economic damage in Germany (Kron and Thumerer, 2002) and the preventive evacuation of about 250000 people in the Netherlands. 


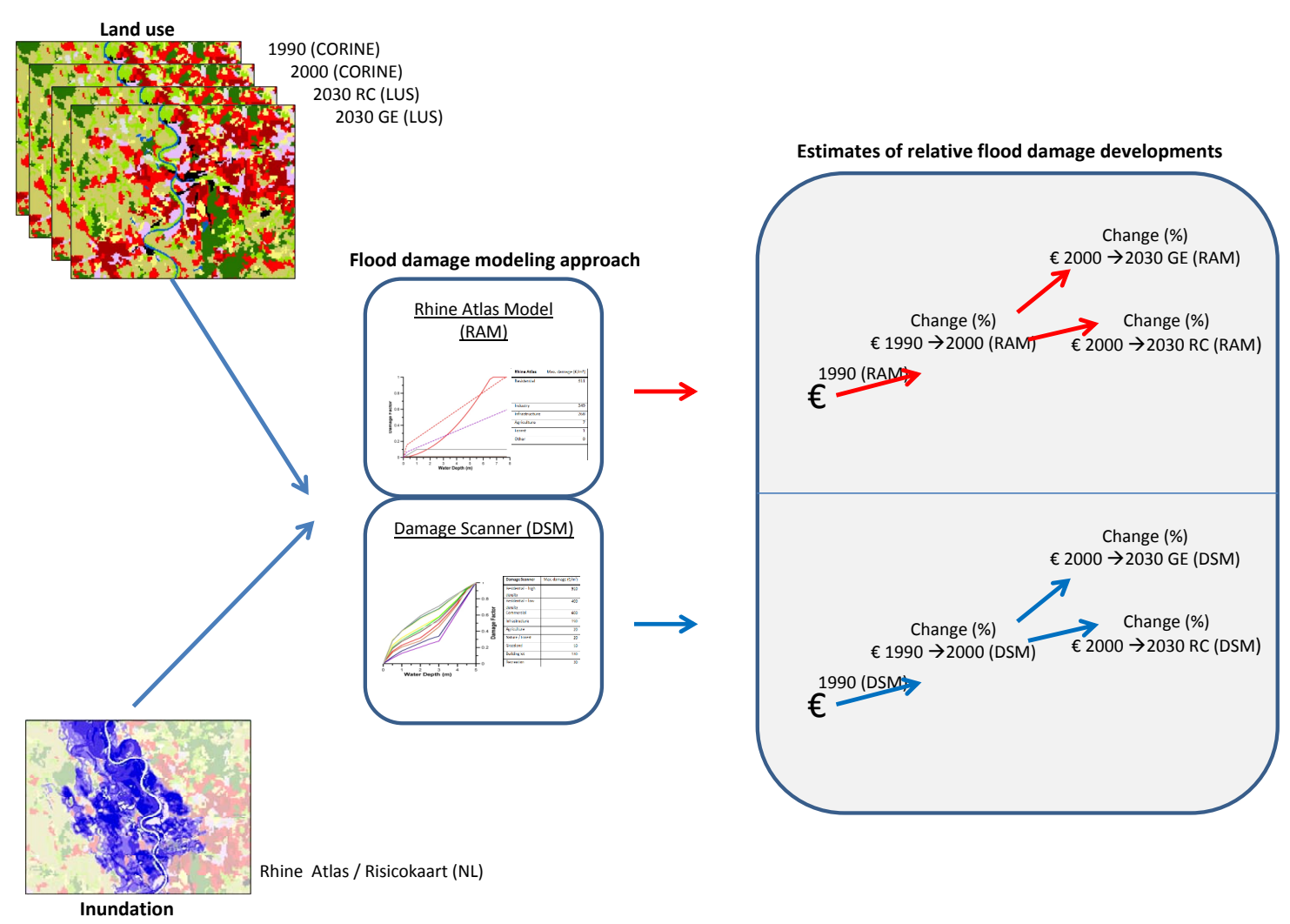

Fig. 1. Flow chart of the input data and method applied to evaluate the reliability of relative estimates of flood damage developments.

\subsection{Inundation data}

For the Rhine and its floodplains up to the Netherlands, we use the inundation map that was developed by the International Commission for the Protection of the Rhine (ICPR, 2001a). A $100 \times 100 \mathrm{~m}$ grid map was derived from the original vector data set that provides information on the flood extent and seven different classes of inundation depths, ranging from $50 \mathrm{~cm}$ to $5 \mathrm{~m}$ and above. For the part of the Rhine in the Netherlands, updated and improved information on potentially inundated areas is available in the form of the Dutch "Risicokaart". The "Risicokaart", which is based on hydro-dynamical modelling, shows the maximum inundation depths that are derived from numerous simulations of dyke breaches (Wouters and Holterman, 2007). It was originally provided at a spatial resolution of $50 \mathrm{~m} \times 50 \mathrm{~m}$ and was resampled to a $100 \mathrm{~m} \times 100 \mathrm{~m}$ resolution grid. The combined inundation map for the Rhine channel shows flood extent and depths for extreme discharge events, with events ranging from an average frequency of occurrence of $1 / 200 \mathrm{yr}$ at the Upper Rhine to $1 / 2000 \mathrm{yr}$ in the Dutch delta area, and has been applied earlier in a study on future flood damage (e.g. te Linde et al., 2011). Only those areas in the Dutch delta that are prone to river flooding from the Rhine were included. Those areas that face flood risk, mainly from coastal storm surges in combination with high but not extreme river discharges, were not included. It should be noted that the inundation map used in the present study does not represent a realistic flooding scenario, because there will never be enough water in a single event to inundate the entire area. Instead, it provides an indication of the potential maximum hazard facing all the economic assets exposed to floods along the Rhine.

\subsection{Land-use information}

Information on land use is based on CORINE land cover grids for the years 1990 and 2000 (Bossard et al., 2000), which are available at a spatial resolution of $100 \mathrm{~m} \times 100 \mathrm{~m}$ from the European Environment Agency. The grids were aggregated to the six and nine land-use classes of the two damage models, respectively (see Table 1). Two land use projections for 2030 were derived from a land use model known as the "Land Use Scanner" (Hilferink and Rietveld, 1999; Loonen and Koomen, 2009), which was adapted for the Rhine basin (te Linde et al., 2011). The "Land Use Scanner" model has been applied in numerous research projects and policy appraisals in the Netherlands and other European countries, including assessments of future flood risk (Borsboom-van Beurden et al., 2007; Aerts et al., 2008; Maaskant et al., 2009; Bouwer et al., 2010; te Linde et al., 2011). The model 
Table 1. Maximum damage values for land-use classes of the Rhine Atlas and the Damage Scanner models (at 2000 prices).

\begin{tabular}{lrllr}
\hline Rhine Atlas & $\begin{array}{r}\text { Max. damage } \\
\left(€ / \mathrm{m}^{2}\right)\end{array}$ & & Damage Scanner & $\begin{array}{r}\text { Max. damage } \\
\left(€ / \mathrm{m}^{2}\right)\end{array}$ \\
\cline { 1 - 1 } Residential & 233 & & Residential - high density & 910 \\
Residential mobile & 55 & & Residential - low density & 400 \\
Industry & 246 & & Commercial & 600 \\
Industry mobile & 82 & & 190 \\
Infrastructure & 250 & & Infrastructure & \\
Infrastructure mobile & 2 & & Agriculture & 20 \\
Agriculture & 7 & & Pasture & 10 \\
Forest & 1 & & Nature/Forest \\
Other & 0 & & Building lot & 130 \\
& & Recreation & 30 \\
\hline
\end{tabular}

is based on microeconomic theory, and uses socio-economic scenarios to simulate land-use patterns on the basis of spatial claims (expected quantity of land-use change), suitability, and policy maps (Fig. 2).

The existing Land Use Scanner model for the Rhine (see te Linde et al., 2011) has been forced with two contrasting socio-economic scenarios to produce future land-use maps (Fig. 2). These scenarios are derived from the EURURALIS project (Verburg et al., 2008; Verburg and Overmars, 2009), and describe future spatial claims for the Rhine area. The Global Economy scenario (GE) assumes a world with high economic and population growth, international economic integration and a strong influence of private interests. A weak government is assumed that enforces little environmental regulation. The GE scenario results in a land-use projection that sees a large increase in urban land use. No restrictions in terms of urban development are applied to areas at risk of flooding due to the weak role of the government assumed for this scenario. In contrast, the Regional Communities scenario (RC) assumes a world with little economic and population growth and a strong regional focus. In this scenario, a strong government is foreseen that enforces strict environmental regulations such as spatial zoning in floodprone areas. The RC scenario leads to a land-use change projection that sees far less urban development, which is considerably restricted in areas at risk from flooding. The GE and $\mathrm{RC}$ scenarios are comparable to the $\mathrm{A} 1$ and $\mathrm{B} 2$ scenarios of the Intergovernmental Panel on Climate Change, respectively (IPCC, 2000). While no probability is attached to each of these two scenarios, we assume that the two scenarios reflect the possible bandwidth of future changes in land use and urban development. For a more detailed description on the downscaling approach and the development of these land-use projections, the reader is referred to te Linde et al. (2011).

\subsection{Damage models}

On the basis of the flood inundation map (Sect. 3.2) and the four land-use maps (Sect. 3.3), two flood damage modelling approaches are used to calculate potential flood damage along the Rhine for the years 1990, 2000, and the two projections for 2030 .

\subsubsection{Rhine Atlas damage model}

The Rhine Atlas damage model (RAM) was developed for the International Commission for the Protection of the Rhine (ICPR, 2001b). The method uses five depth-damage functions to calculate potential flood damage. The functions were constructed on the basis of the HOWAS database, and are thus empirical in nature, even though additional expert judgement has been used to select and combine entries from the HOWAS database (ICPR, 2001b). Even though the RAM has been developed to estimate potential flood damage along the trans-boundary river Rhine, it is thus largely based on empirical damage data from Germany.

The depth-damage functions are linked to five re-classified CORINE land cover classes, of which three reflect urban land-use types (residential, industrial, and infrastructure). For the three urban categories, separate damage values for property and contents are used in the RAM (see Table 1) (ICPR, 2001a). The model considers direct tangible flood damage that is caused by physical contact between floodwater and the economic assets at risk. Not reflected in the RAM is indirect damage, such as losses due to the disruption of production processes, and also intangible damage, such as loss of life.

\subsubsection{Damage Scanner model}

The Damage Scanner model (DSM) also calculates potential flood damage by linking information on land use and 

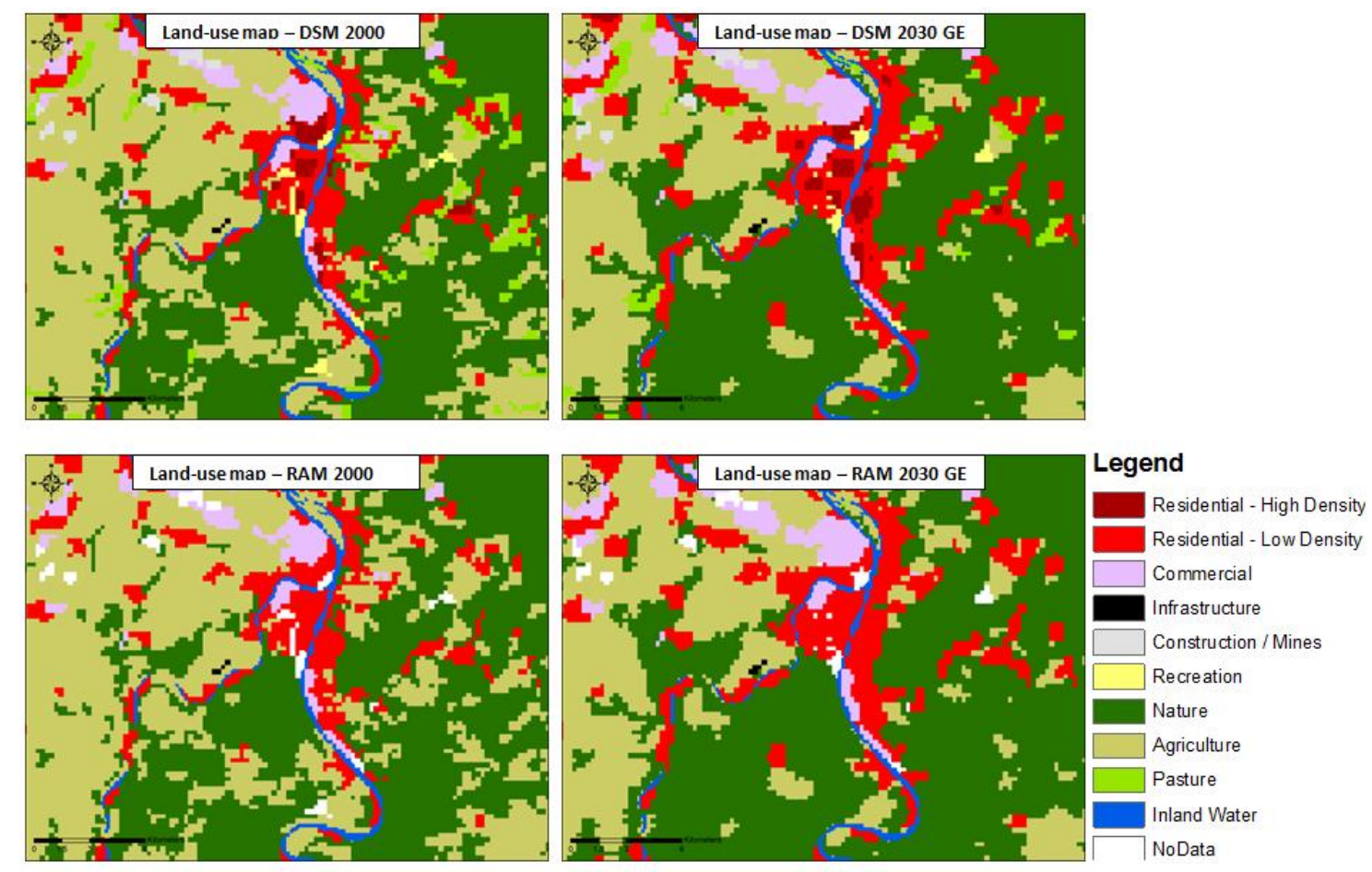

Fig. 2. Land use maps for 2000 and 2030 (GE scenario) used as input for the RAM and the DSM.

information on inundation depth with seven depth-damage functions (see Table 1 and Fig. 3). It has been used in various studies that assess the impact of future land use on potential flood damage at various scales: amongst others, along the Rhine and especially in the Rhine delta (Aerts et al., 2008; Bouwer et al., 2010; te Linde et al., 2011; de Moel et al., 2011). As the functions of the DSM are based on the HISSSM, which is the standard software in the Netherlands to assess flood damage, they are based on some empirical information as well as expert judgment and thus are mainly synthetic in nature. The model predominantly estimates direct tangible damage. However, the DSM also implicitly includes a share of 5 per cent indirect damage. This latter type of damage reflects potential losses in economic turnover due to traffic interruption or emergency costs.

\subsubsection{Comparison of the RAM versus the DSM}

Differences between the two models can be found both in the applied damage curves and in the maximum damage values linked to the respective damage categories. Figure 3 displays the shape of the damage curves of the RAM and the DSM. These curves are used to calculate the fraction of the maximum damage (damage factor) occurring in a grid cell, based on the respective inundation depth.

When comparing the residential damage curves from both models (solid red lines), it becomes apparent that the curve of the DSM is steeper compared with that of the RAM. For instance, at $4 \mathrm{~m}$ water depth, the RAM curve gives a damage factor of about 0.4 , while the DSM curve gives a damage factor of about 0.8 . In addition, both models differ in their assumption at which water level the maximum damage is reached. According to the DSM, maximum damage of all land-use types is reached at a water level of about $5 \mathrm{~m}$. In contrast, the RAM assumes that a water level of $5 \mathrm{~m}$ results in about 60 per cent of the maximum damage for residential and commercial areas. These differences in the functions reflect the uncertainties still associated with depth-damage curves in flood damage modelling (e.g. Freni et al., 2010). These uncertainties stem from the large variability of observed damage even among similar elements at risk. Two buildings that share the same physical characteristics and that are situated next to each other can nevertheless experience largely different amounts of damage during the same flood event. This is because not only flood impact parameters, such as flow velocity and the contamination of flood water, but also flood resistance parameters, such as flood experience and precautionary measures, can significantly differ even within short distances (Merz et al., 2010).

Moreover, both models differ substantially in terms of the maximum damage values that are linked to the damage categories, represented by the respective land-use types. An overview of the maximum damage values at 2000 price levels for respective damage categories according to both models is provided in Table 1. 

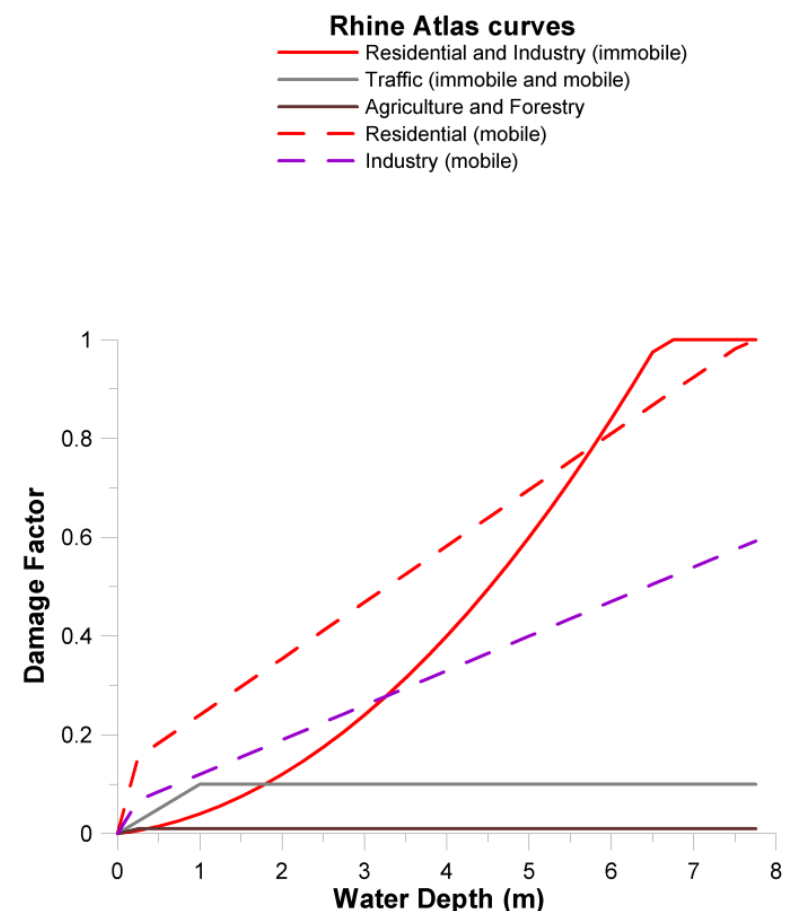
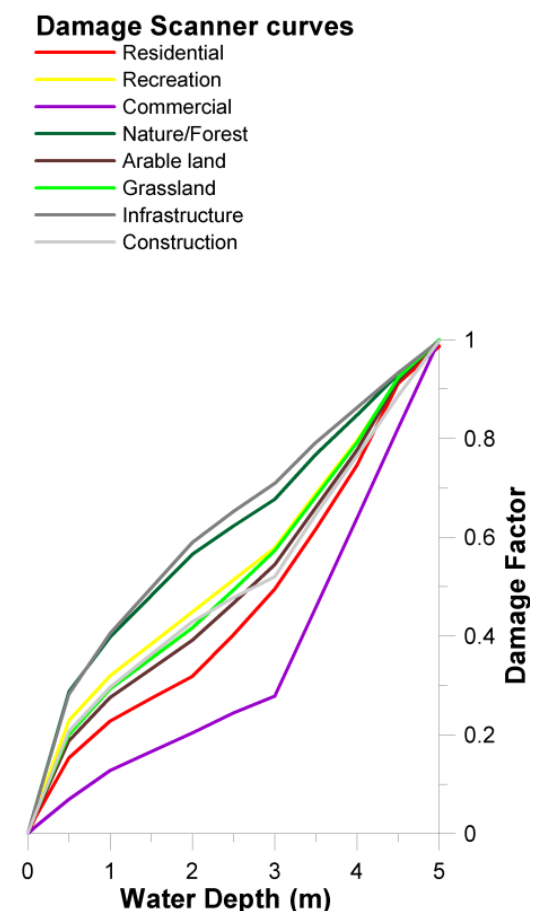

Fig. 3. Damage curves for the Rhine Atlas and the Damage Scanner model (Adapted from de Moel and Aerts, 2011).

Table 1 shows that the maximum damage for similar damage categories is significantly higher in the DSM compared with the RAM. For instance, the residential category of the RAM has a maximum damage of $288 € \mathrm{~m}^{-2}$ (sum of residential and residential mobile), while the maximum damage of the DSM is $910 € \mathrm{~m}^{-2}$ for high density urban areas, and $400 € \mathrm{~m}^{-2}$ for low density urban areas. As a comparison, the standard flood loss model in the UK estimates a maximum damage value of $750 £ \mathrm{~m}^{-2}\left(865 € \mathrm{~m}^{-2}\right)^{2}$ for a residential home (Penning-Rowsell et al., 2005). Likewise, the industrial damage category also shows a marked difference between the RAM and the DSM: it has a maximum damage of $328 € \mathrm{~m}^{-2}$ in the RAM compared with $600 € \mathrm{~m}^{-2}$ in the DSM. While these urban land-use classes have a maximum damage that differs roughly by a factor of 2 , the difference between both agricultural land use and nature areas is even larger, by a factor of 2.8 and 20 , respectively.

There are a number of reasons for the large differences in terms of maximum damage values between the RAM and the DSM. While the RAM uses depreciated asset values, the DSM is, at least in some instances, based on replacement costs, such as those for building structures and contents (Briene et al., 2002). Differences in price levels among the riparian countries cannot serve as an explanation for the large variations in terms of maximum damage values, as purchasing power is only marginally different (see ICPR, 2001b). Damage to vehicles, which can make a significant contribution to total damage of 2 per cent to 7 per cent (ICPR, 2001a), is not considered in the maximum damage values of the RAM (ICPR, 2001a), while replacement values for vehicles are included in the DSM (Briene et al., 2002). The explanation for the very large difference in the maximum damage of agricultural areas between the two models is that agricultural practices in the Netherlands are more capital intensive (ICPR, 2001a). Additionally, the DSM takes into account that, in grid cells with an agricultural land use, there are also buildings with inventory present and not just crops. Furthermore, the DSM also implicitly comprises approximately 5 per cent of indirect damage as a surcharge on direct damage. Indirect damage, which can make up a substantial share of total flood damage, refers to losses that are induced by the flood event itself but occur with a time delay or outside the flooded area. Hallegatte (2008), for instance, published a study on the relation between direct and indirect damage. He investigates the response of the regional economy of Louisiana to the landfall of hurricane Katrina using an input-output model. The simulation results show that disturbed economic processes aggravate direct damage. While the direct damage of hurricane Katrina is estimated at $\$ 107 \mathrm{bn}$, the indirect effects are estimated at an additional $\$ 42 \mathrm{bn}$, which is hence 28 per cent of total losses (Hallegatte, 2008).

\footnotetext{
${ }^{2}$ According to exchange rates of 19 August 2011
} 
Table 2. Potential flood damage along the Rhine (Million $€$ ) for different time-steps, according to the Rhine Atlas and the Damage Scanner damage model.

\begin{tabular}{lrrrr}
\hline & 1990 & 2000 & $2030 \mathrm{RC}$ & $2030 \mathrm{GE}$ \\
\hline Rhine Atlas model & 74591 & 77749 & 86982 & 108158 \\
Damage Scanner model & 290883 & 300463 & 323608 & 380684 \\
Difference factor between models & 3.8 & 3.8 & 3.7 & 3.5 \\
\hline
\end{tabular}

\section{Results and discussion}

\subsection{Absolute flood damage estimates}

An overview of potential damage along the Rhine according to the RAM and the DSM model for 1990, 2000, and to the two socio-economic scenarios (2030), as well as their difference factors, is provided in Table 2. Both model results differ significantly in terms of absolute damage estimates by a factor ranging from 3.5 to 3.8. In general, the RAM gives much lower results compared with the DSM. The results are in line with several other studies that have stressed the variations related to the assessment of direct flood damage (e.g. Merz et al., 2004; Apel et al., 2008; Freni et al., 2010). De Moel and Aerts (2011), for instance, estimate flood damage for a Dutch polder area using three different damage modelling approaches, and find differences up to a factor of 4 .

The large variations in absolute damage estimates can be attributed to existing uncertainties in the shapes of damage curves and to methodological differences for estimating the underlying exposed asset values of the respective damage categories, which were discussed in Sect. 3.4.3.

To identify whether variations between the models in absolute damage estimates result from differences in the underlying maximum damage values or from differences in the damage curves, we performed an additional model-run with the RAM, using the maximum damage values of the DSM. This model-run is referred to as RAM ${ }^{\mathrm{DSM}}$. By comparing the results of the RAM ${ }^{\mathrm{DSM}}$ with the results of the RAM, we can estimate how the differences in maximum damage values influence absolute damage estimates, because both the RAM and the RAM ${ }^{\mathrm{DSM}}$ use the same damage functions. By comparing the results of the DSM with the results of the $\mathrm{RAM}^{\mathrm{DSM}}$, we can estimate how the differences in damage functions influence the absolute damage estimates, because both the DSM and the RAM ${ }^{\mathrm{DSM}}$ use the same maximum damage values. An overview of the absolute damage estimates for the RAM ${ }^{\mathrm{DSM}}$ and the difference factors between the RAM and the RAM ${ }^{\mathrm{DSM}}$, and between the DSM and the $\mathrm{RAM}^{\mathrm{DSM}}$, are provided in Table 3. It is shown that differences in the maximum damage values have a smaller influence on variations in absolute damage estimates between the two models (by a factor 1.8 for all time steps) than differences in the functions (by a factor of 1.93-2.13).
Table 3. Absolute damage estimates of the model-run RAM ${ }^{\mathrm{DSM}}$ and difference factors between the RAM and the RAM ${ }^{\mathrm{DSM}}$, and between the DSM and the RAM ${ }^{\mathrm{DSM}}$.

\begin{tabular}{lrrrr}
\hline & 1990 & 2000 & $2030 \mathrm{RC}$ & $2030 \mathrm{GE}$ \\
\hline RAM $^{\text {DSM }}$ & 136674 & 142366 & 159389 & 197678 \\
Diff. due to max. damage value* & 1.83 & 1.83 & 1.83 & 1.83 \\
Difference due to function** & 2.13 & 2.11 & 2.03 & 1.93 \\
\hline & & & & \\
* RAM ${ }^{\text {DSM }}$ vs. RAM (difference factor). & & & \\
** DSM vs. RAM ${ }^{\text {DSM }}$ (difference factor).
\end{tabular}

Other studies that have investigated the influence of different damage functions on absolute damage estimates have come to similar conclusions. For instance, Apel et al. (2009) compare the results of several damage modelling approaches with recorded flood damage and find that differences in damage curves can lead to relative errors ranging from -87 per cent to 34 per cent. Since the same exposure data was used for all model runs, the influence of different maximum damage values on absolute damage estimates was not assessed in the study of Apel et al. (2009).

\subsection{Estimates of relative changes in the development of potential flood damage}

The large differences in absolute damage estimates that result from the application of the two different damage modelling approaches is the reason for evaluating the reliability of relative estimates. We therefore assess the results from the two models in terms of relative changes in potential flood damage for the periods 1990 to 2000 and 2000 to 2030 (using the GE and RC scenarios). As can be seen from Fig. 3, the RAM model estimates consistently higher relative increases in potential flood damage compared with the DSM. While the RAM model foresees a relative increase of 39.1 per cent for the GE scenario and 11.8 per cent for the RC scenario, the DSM projects an increase of 27.3 per cent and 8.4 per cent, respectively. For all time steps, the RAM model gives relative estimates, which are about 1.1 to 1.4 times higher than the DSM model. It should be noted that this variation is considerably smaller compared with differences observed for the absolute damage estimates of the two models (Table 2). This finding is in line with previous studies, which showed that estimates of proportional changes in flood damage are much more robust compared with absolute estimates (de Moel and Aerts, 2011). Moreover, differences between the two models when estimating relative changes are considerably smaller compared with uncertainties inherent in future projections of socio-economic development, as reflected by the two contrasting land-use scenarios. With respect to potential damage, the two land-use projections differ by more than a factor of 3 for both models (Fig. 4). To identify whether variations between the models in terms of relative estimates result 


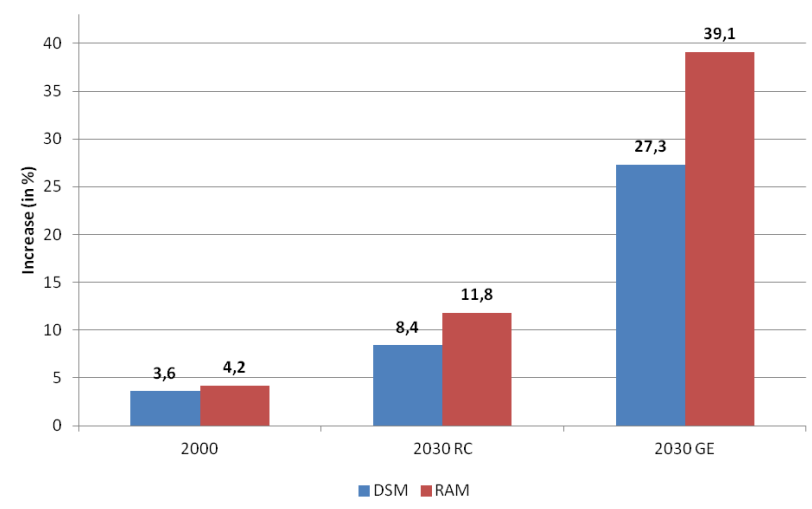

Fig. 4. Relative increase (in \%) in potential flood damage along the Rhine, according to the Rhine Atlas and the Damage Scanner models. Note: 2000 values are compared with 1990, and 2030 values are compared with those of 2000.

from differences in the underlying maximum damage values or from differences in the damage curves, we again compare the RAM ${ }^{\mathrm{DSM}}$ with the RAM and with the DSM. An overview of the relative estimates of flood damage developments of the $\mathrm{RAM}^{\mathrm{DSM}}$ and the difference factor between the relative estimates of the RAM ${ }^{\mathrm{DSM}}$ and RAM, and between the relative estimates of the RAM ${ }^{\mathrm{DSM}}$ and the DSM are provided in Table 4. It is shown that differences in the relative estimates of flood damage developments are predominantly influenced by differences in the damage functions between the two models. The RAM and the RAM ${ }^{\mathrm{DSM}}$, which use the same damage functions but different maximum damage values, perform almost identically (by a factor of 0.99 to 1.01). In contrast, the comparison between the RAM ${ }^{\mathrm{DSM}}$ and the DSM, which use the same maximum damage values but different functions, show difference factors of 1.15 to 1.42 .

The fact that differences in maximum damage values have hardly an influence on relative estimates of flood damage developments in the present study can be explained by the proportion of grid cells that change in land use, and grid cells that remain unchanged between two time steps. For instance, when looking at the GE scenario, only 2.5 per cent of all grid cells change in land use between 2000 and 2030 in the flood prone area. For the majority of grid cells that do not change in land use, differences in maximum damage values between the two models have no influence on relative estimates of flood damage developments. This is because, even though the application of the RAM and the RAM ${ }^{\mathrm{DSM}}$ leads to different absolute damage values due to the differences in maximum damage values, both models foresee no change in damage between 2000 and 2030 GE for a grid cell that does not change in land use. In contrast, differences in the damage functions between the two models lead to changes in relative estimates for all grid cells. Because only a small share of grid cells change in land use, the influence of differences in maximum damage values on relative estimates of changes in the development of flood damage is small.
Table 4. Relative estimate of damage developments of the modelrun RAM $^{\mathrm{DSM}}$ and difference factors between relative estimates of the RAM and the RAM ${ }^{\mathrm{DSM}}$, and between the RAM ${ }^{\mathrm{DSM}}$ and the DSM.

\begin{tabular}{lrrr}
\hline & $1990-2000$ & $2000 \mathrm{RC}$ & $2000 \mathrm{GE}$ \\
\hline RAM $^{\text {DSM }}$ & $4.16 \%$ & $11.96 \%$ & $38.85 \%$ \\
Diff. due to max. damage values* $^{*}$ & 0.99 & 1.01 & 0.99 \\
Diff. due to function** & 1.15 & 1.41 & 1.42 \\
\hline
\end{tabular}

* RAM ${ }^{\mathrm{DSM}}$ to RAM (difference factor).

**RAM ${ }^{\mathrm{DSM}}$ to DSM (difference factor).

A different result is obtained when focusing only on grid cells that change in land use. For those grid cells, the influence of difference in maximum damage values is substantial, and can be explained by the different weighting of respective damage categories within the individual models. Table 5 shows the percentage that each damage category, represented by land-use classes, contributes to total damage in 2000 for both models. It is shown that urban land-use classes (residential and commercial) contribute about 98 per cent of the total damage in the RAM model. In the DSM model, this percentage is considerably lower (79 per cent), and agricultural land use also contributes significantly to the overall damage (14.8 per cent).

The varying contributions of the respective damage categories to the total damage of the two models is a result of the different ratio of maximum damage values across the assigned damage categories within each of the two models (see Table 1). For example, the difference between the maximum damage of residential and agricultural land use is about a factor of $41\left(288 € \mathrm{~m}^{-2}\right.$ divided by $\left.7 € \mathrm{~m}^{-2}\right)$ in the RAM model, while the difference between low-density residential areas, which comprise most of the residential areas, and agriculture differs only by a factor of $20\left(400 € \mathrm{~m}^{-2}\right.$ divided by $20 € \mathrm{~m}^{-2}$ ) in the DSM model. Because these ratios are so different, a change from agriculture to low-density residential land use in the flood-prone area has a different effect on the increase in potential flood damage between the two models. This will be further illustrated below by looking at the land-use change and the corresponding change in flood damage between 2000 and 2030 (GE scenario).

The GE scenario represents a "strong growth scenario", which results in a considerable increase in urban land-use types, mainly at the expense of agricultural areas. Table 6 provides a matrix of net changes among all land-use classes between 2000 and 2030 (GE), and insights into the specific changes that occur among land-use types between 2000 and 2030 GE. The fact that net changes are presented means that conversions between two land-use types in both directions are considered. It shows that predominantly agricultural areas change into low-density residential (32328 hectares) and commercial areas (6504 hectares). The increase in 
Table 5. Relative share of respective land-use types to total damage (2000) for the Rhine Atlas and the Damage Scanner models.

\begin{tabular}{|c|c|c|c|c|}
\hline \multirow[b]{2}{*}{ Land use } & \multicolumn{2}{|c|}{ Rhine Atlas } & \multicolumn{2}{|c|}{ Damage Scanner } \\
\hline & Total damage $(€)$ & Total damage $(\%)$ & Total damage (€) & Total damage $(\%)$ \\
\hline Residential & 58248 & 74.9 & 187707 & 62.5 \\
\hline Commercial & 17919 & 23.0 & 49359 & 16.4 \\
\hline Infrastructure & 1231 & 1.6 & 6339 & 2.1 \\
\hline Nature/Forestry & 6 & 0.0 & 7626 & 2.5 \\
\hline Agriculture & 346 & 0.4 & 44487 & 14.8 \\
\hline Construction/Mines & - & - & 2840 & 0.9 \\
\hline Recreation & - & - & 2104 & 0.7 \\
\hline Total & 77750 & 100 & 300463 & 100 \\
\hline
\end{tabular}

high-density urban areas is mainly due to the conversion of formerly low-density residential areas (Table 6), and thus reflects an increase in urban density. Important changes among land-use types that lead to large changes in potential flood damage are highlighted in colour.

These transformations from mainly agricultural areas to urban land-use types lead to a large increase in potential flood damage for these grid cells, given the importance of urban areas in both models. However, differences exist between the two models, because in the RAM model, urban damage categories make up a larger share of total damage compared with the DSM model (see Table 5). This also leads to a larger increase in potential damage for grid cells that change in land use according to the RAM over time compared with the DSM.

To demonstrate this in greater detail, only those grid cells that change between agriculture and low-density residential areas between 2000 and $2030 \mathrm{GE}$ are extracted and analysed separately with respect to absolute and relative changes in potential flood damage. The analysis shows that the shift of the 32328 hectares from agricultural to low-density residential areas results in a damage increase for these grid cells of 478 per cent in the RAM model, while it leads to an increase of 341 per cent according to the DSM model (Table 7). In addition to the predominant change between agricultural and low-density residential areas, other important land-use changes with a large effect on potential damage were analysed the same way. An overview of the specific effect of important changes among land-use types in terms of absolute and relative changes in potential damage for the two models is provided in Table 7 .

Insights into the question: "which of the two models provides more reliable estimates of flood damage developments for grid cells that change in land use?", could be provided by information on how different damage categories have contributed to overall flood damage for observed flood events along the Rhine. Recorded damage data of an extreme event would be of interest for the present study, because inundation maps of potential extreme flood events are used as input for the two damage models. However, according to our knowledge, such detailed data that breaks down recorded flood damage into different damage categories is not available for the Rhine. This also holds true in general: while the hydrological parameters of a flood are commonly evaluated in the aftermath of an event (e.g. Landesamt für Umwelt BadenWürttemberg, 2000), comprehensive data on observed damage following from these events is scarce (e.g. Sächsische Staatskanzlei, 2003).

A major flood event, for which more detailed damage data could be obtained, occurred along the Elbe in 2002 and predominantly affected the federal state of Saxony (Sächsische Staatskanzlei, 2003). Table 8 shows overall recorded damage for this event, and also provides the contribution of several damage categories to overall losses. Even though these data are not necessarily comparable to the Rhine due to geographical differences, two aspects also seem to provide valid insights for the present study. First, the data of the Elbe flood strongly suggest that both models remarkably underestimate damage to infrastructure. According to the RAM damage model and the DSM model, infrastructure does not significantly contribute to overall losses, with a share of 1.6 per cent and 2.1 per cent, respectively (see Table 5). However, during the Elbe flood, damage to municipal infrastructure alone comprised about 20 per cent of overall losses. Within this damage category, damage to roads and bridges (36 per cent) and damage to water protection and flood defences (11 per cent) were the largest items. Also, with regard to state-run infrastructure, which made up 15 per cent of overall reported losses, damage to roads and bridges, as well as to water protection and flood defences, were the two largest items with 12 and 63 per cent, respectively. The fact that damage to roads and bridges is hardly reflected in meso-scale flood damage assessments, as also applied in the present study, can be explained by the resolution of the land-use maps that are usually employed in such studies. Often, the latter have a resolution of $100 \mathrm{~m} \times 100 \mathrm{~m}$ or coarser. Because they have 
Table 6. Matrix of net changes (in hectares) among the respective land use types between 2000 and 2030 GE.

\begin{tabular}{|c|c|c|c|c|c|c|c|c|}
\hline & Residential HD & Residential LD & Commercial & Infrastructure & Construction & Recreation & Nature & Agriculture \\
\hline Residential HD & 0 & & & & & & & \\
\hline Residential LD & 10499 & 0 & & & & & & \\
\hline Commercial & -1398 & -599 & 0 & & & & & \\
\hline Infrastructure & -26 & -2 & -20 & 0 & & & & \\
\hline Construction & 6 & 23 & 22 & 0 & 0 & & & \\
\hline Recreation & -282 & 1410 & 369 & 13 & 0 & 0 & & \\
\hline Nature & -26 & 4776 & 1071 & 13 & 17 & 669 & 0 & \\
\hline Agriculture & 1253 & 32328 & 6504 & 136 & 125 & 3464 & 10985 & 0 \\
\hline Total Increase (ha) & 10026 & 27437 & 9943 & 210 & 91 & 2623 & 4465 & -54795 \\
\hline
\end{tabular}

Note: the specific effect of the highlighted changes among land-use types in terms of changes in potential damage is provided in Table 7.

Table 7. Specific effect of important changes among land-use types in terms of potential flood damage for the two models.

\begin{tabular}{|c|c|c|c|c|c|c|c|c|}
\hline \multirow[b]{2}{*}{ Net land-use change (2000-2030 GE) } & \multicolumn{4}{|c|}{ Damage Scanner (DS) } & \multicolumn{4}{|c|}{ Rhine Atlas model (RA) } \\
\hline & 2000 & $2030 \mathrm{GE}$ & Absolute & Relative (\%) & RA 2000 & RA 2030 & Absolute & Relative (\%) \\
\hline Residential (LD) and Residential (HD) & 1831 & 3270 & 1438 & 79 & 639 & 639 & 0 & 0 \\
\hline Nature and Residential (LD) & 30 & 460 & 430 & 1413 & 0.02 & 210 & 210 & 876936 \\
\hline Agriculture and Commercial & 139 & 1316 & 1176 & 843 & 32 & 482 & 450 & 1402 \\
\hline
\end{tabular}

Table 8. Recorded flood damages in Saxony during the Elbe flood in 2002

\begin{tabular}{lrr}
\hline & \multicolumn{2}{c}{ Observed damage } \\
\cline { 2 - 3 } & Absolute & $\%$ of \\
& (Mill. $€$ ) & total \\
\hline Residential Buildings & 1706 & 27.5 \\
Building contents & 529 & 8.5 \\
Industry & 1420 & 22.9 \\
Municipal Infrastructure & 1287 & 20.8 \\
state-run infrastructure & 928 & 15.0 \\
Costs of disaster operation & 136 & 2.2 \\
Cultural facilities & 111 & 1.8 \\
Agricuture and Forestry & 79 & 1.3 \\
\hline Total & 6196 & 100.0 \\
\hline
\end{tabular}

Source: adapted from Sächsische Staatskanzlei (2003).

such their narrow shapes, infrastructural elements are underrepresented in land-use maps of this resolution. Bouwer et al. (2009) show that the share of potential flood damage to infrastructure in overall losses increases from 3.9 to 8 per cent in a Dutch polder area, when switching from a $100 \mathrm{~m} \times 100 \mathrm{~m}$ to a $25 \mathrm{~m} \times 25 \mathrm{~m}$ grid resolution. Second, the recorded damage data of the Elbe flood suggest that both models might overestimate the contribution of residential areas to overall losses. According to the RAM and the DSM, the residential damage category contributes 75 per cent and 62 per cent, respectively (see Table 5). However, during the Elbe flood, damage to residential buildings and their contents comprised 36 per cent of overall losses. Since these observations are based on a single event only, it should be noted that, in order to draw more general conclusions, more data on recorded flood damage and the contribution of different damage categories to overall losses is necessary.

\section{Conclusions}

The present study has investigated the reliability of estimates of relative changes in the development of potential flood damage with regard to the uncertainties stemming from flood damage modelling approaches. We find that two flood damage modelling approaches differ by a factor of 3.5 to 3.8 for absolute damage estimates. These differences are attributed to both uncertainties in the depth-damage curves and methodological differences for estimating the underlying maximum damage values of the respective damage categories. Variations in maximum damage values between the two models are found to have a smaller influence (by a factor of 1.8) than variations in the damage curves (by a factor of 1.9-2.1). The variations in maximum damage values stem from different methodological approaches, and from the choice of economic parameters, such as depreciated asset values versus replacement cost, mean insured value or standardized constructions costs, which are used to derive the 
asset values linked to the damage curves. As this can lead to large differences in terms of absolute damage estimates, it should always be clearly specified which type of damage and assets are taken into account, and how the attached asset values were derived.

With respect to relative estimates of flood damage developments, it was found that, when estimating relative flood damage developments, both modelling approaches provide very similar results that differ by about a factor of 1.4. This number is considerably lower than it is for the difference in absolute estimates between the models, and also smaller than it is for the uncertainty inherent in projections of future exposure, as represented by contrasting land-use projections. With respect to potential damage, the two land-use projections applied in the present study result in differences in damage of more than a factor of 3 . In contrast to variations in absolute damage estimates, the differences between the damage modelling approaches in terms of relative changes can be attributed predominantly to the differences in the damage functions between the models. This is because the differences in maximum damage values only have an influence on grid cells that change in land use. As only a relatively small share of the grid cells changes between the two time steps, e.g. 2.5 per cent of all grid cells change between 2000 and $2030 \mathrm{GE}$, the differences in maximum damage values between the two models have hardly any influence on relative estimates of flood damage developments. The differences in damage functions, in contrast, apply to all grid cells in the flood-prone area, which explains the larger influence on variations in relative estimates, with difference factors ranging from 1.1 to 1.4 .

These findings provide valuable insights for intergovernmental river-basin organizations like the ICPR. Such organizations are increasingly required to engage in trans-boundary flood risk assessments under the EU Water Framework Directive, and usually need to choose among various flood damage modelling approaches when doing so. We show that the influence of different modelling approaches on estimates of relative changes in the development of flood damage is small compared with other sources of uncertainties encountered in flood damage projections.

In order to improve the reliability of relative estimates of flood damage developments, future research should focus on reducing the uncertainties of stage-damage functions, which originates from the huge variability of observed damage even among similar elements at risk. Although it is only possible to integrate this enormous variability in flood damage modelling approaches to a limited extent, it has been shown that model performance can be improved by integrating several damage-influencing parameters in multi-parameter damage modelling (e.g. Elmer et al., 2010). As this requires detailed data on damage processes at the level of individual objects, data collection after flood events remains a crucial activity.
Acknowledgements. The authors would like to thank Jose Barredo and an anonymous referee for their valuable comments. This research was partly carried out in the framework of the Dutch National Research Programme Knowledge for Climate (www.knowledgeforclimate.nl), which is co-financed by the Ministry of Housing, Spatial Planning and the Environment (VROM). We are grateful to DG Water of Rijkswaterstaat for providing additional funding to undertake this research. We thank Ton Sprong and Hendrik Buiteveld from DG Water for their valuable input. Anne Schulte-Wülwer-Leidig from the International Commission for the Protection of the Rhine kindly provided the inundation maps of the Rhine Atlas. Finally, we thank our colleague Wouter Botzen for his comments on an earlier version of this paper.

Edited by: M.-C. Llasat

Reviewed by: J. I. Barredo and another anonymous referee

\section{References}

ABI: The financial risk of climate change, Research paper no. 19, Association of British Insurers, London, 2009.

Aerts, J. C. J. H., Sprong, T., and Bannink, B. A. (Eds.): Aandacht voor veiligheid, Leven met Water, Klimaat voor Ruimte, DG Water, 2008.

Apel, H., Merz, B., and Thieken, A. H.: Quantification of uncertainties in flood risk assessments, Int. J. River Basin Manage., 6, 149-162, 2008.

Apel, H., Aronica, G. T., Kreibich, H., and Thieken, A. H.: Flood risk analyses - how detailed do we need to be?, Nat. Hazards, 49, 79-98, 2009.

Borsboom-van Beurden, J. A. M., Bakema, A., and Tijbosch, H.: A land-use modelling system for environmental impact assessment; recent applications of the lumos toolbox, in: Modelling land-use change: Progress and applications, edited by: Koomen, E., Stillwell, J., Bakema, A., and Scholten, H. J., Springer, Dordrecht, 281-296, 2007.

Bossard, M., Feranec, J., and Otahel, J.: Corine land cover technical guide - addendum 2000, European Environment Agency, Copenhagen, 2000.

Bouwer, L. M., Bubeck, P., Wagtendonk, A. J., and Aerts, J. C. J. H.: Inundation scenarios for flood damage evaluation in polder areas, Nat. Hazards Earth Syst. Sci., 9, 1995-2007, doi:10.5194/nhess-9-1995-2009, 2009.

Bouwer, L. M., Bubeck, P., and Aerts, J. C. J. H.: Changes in future flood risk due to climate and development in a dutch polder area, Glob. Environ. Change - Human and Policy Dimensions, 20, 463-471, 10.1016/j.gloenvcha.2010.04.002, 2010.

Briene, M., Koppert, S., Koopmann, A., and Verkennis, A.: Financiele onderbouwing kengetallen hoogwaterschade, Netherlands Economic Institute (NEI), Rotterdam, 2002.

Büchele, B., Kreibich, H., Kron, A., Thieken, A., Ihringer, J., Oberle, P., Merz, B., and Nestmann, F.: Flood-risk mapping: contributions towards an enhanced assessment of extreme events and associated risks, Nat. Hazards Earth Syst. Sci., 6, 485-503, doi:10.5194/nhess-6-485-2006, 2006.

de Moel, H. and Aerts, J. C. J. H.: Effect of uncertainty in land use, damage models and inundation depth on flood damage estimates, Nat. Hazards, 58, 407-425, 2011. 
de Moel, H., van Alphen, J., and Aerts, J. C. J. H.: Flood maps in Europe - methods, availability and use, Nat. Hazards Earth Syst. Sci., 9, 289-301, doi:10.5194/nhess-9-289-2009, 2009.

de Moel, H., Aerts, J. C. J. H., and Koomen, E.: Development of flood exposure in the Netherlands during the 20th and 21st century, Glob. Environ. Change - Human and Policy Dimensions, 21, 620-627, 2011.

Dircke, P., Aerts, J. C. J. H., and Molenaar, A.: Connecting delta cities - Sharing knowledge and working on adaptation to climate change, Rotterdam, 2010.

Dutta, D., Herath, S., and Musiakec, K.: A mathematical model for flood loss estimation, J. Hydrol., 277, 24-49, 2003.

Elmer, F., Thieken, A. H., Pech, I., and Kreibich, H.: Influence of flood frequency on residential building losses, Nat. Hazards Earth Syst. Sci., 10, 2145-2159, doi:10.5194/nhess-10-21452010, 2010.

EU: Directive 2007/60/EC of the European Parliament and of the Council of 23 October 2007 on the assessment and management of flood risks, Commission of the European Communities (EU), Brussels, Belgium, 2007.

Feyen, L., Barredo, J. I., and Dankers, R.: Implications of global warming and urban land-use change on flooding in Europe, in: Water and urban development paradigms, edited by: Feyen, J., Shannon, K., and Neville, M., Taylor § Francis, London, 217225, 2009.

Freni, G., La Loggia, G., and Notaro, V.: Uncertainty in urban flood damage assessment due to urban drainage modelling and depthdamage curve estimation, Water Sci. Technol., 61, 2979-2993, 2010.

Hall, J. W., Sayers, P. B., and Dawson, R. J.: National-scale assessment of current and future flood risk in england and wales, Nat. Hazards, 36, 147-164, 2005.

Hallegatte, S.: An adaptive regional input-output model and its application to the assessment of the economic cost of katrina, Risk Analysis, 28, 779-799, doi:10.1111/j.1539-6924.2008.01046.x, 2008.

Hallegatte, S.: Strategies to adapt to an uncertain climate change, Glob. Environ. Change - Human and Policy Dimensions, 19, 240-247, doi:10.1016/j.gloenvcha.2008.12.003, 2009.

Hilferink, M. and Rietveld, P.: Land use scanner: An integrated gis model for long-term projections of land use in urban and rural areas, J. Geogr. Syst., 1, 155-177, 1999.

ICPR: Atlas of flood danger and potential damage due to extreme floods of the Rhine, International Commission for the Protection of the Rhine, Koblenz, 2001a.

ICPR: Übersichtskarten der Überschwemmungsgefährung und der möglichen Vermögensschäden am Rhein, Abschlussbericht: Vorgehensweise zur Ermittlung der möglichen Vermögensschäden, Internationale Komission zum Schutz des Rheins, Wiesbaden, Heidelberg, Nijmwegen, München, $2001 \mathrm{~b}$.

ICPR: Nachweis der Wirksamkeit von Massnahmen zur Minderung der Hochwasserstände im Rhein infolge der Umsetzung des Aktionsplans Hochwasser bis 2005, Internationale Komission zum Schutz des Rheins, Koblenz, 2006.

ICPR: Communique of the 14th conference of Rhine ministers, Bonn (18.10.07), International Commission for the Protection of the Rhine, 2007.

ICPR: The rhine: A river and its relations, International Commission for the Protection of the Rhine, Koblenz, 2008.
IPCC: Emission scenarios: Special report of the Intergovernmental Panel on Climate Change, Cambridge University Press, Cambridge, UK, 2000.

IPCC: Climate change 2007: The physical science basis, Contribution of Working Group I to the Fourth Assessment Report of the Intergovernmental Panel on Climate Change, Cambridge University Press, 2007.

Jonkman, S. N., Vrijling, J. K., and Vrouwenvelder, A. C. W. M.: Methods for the estimation of loss of life due to floods: A literature review and a proposal for a new method, Nat. Hazards, 46, 353-389, 2008.

Klijn, F., Baan, P. J. A., De Bruijn, K. M., and Kwadijk, J.: Overstromingsrisico's in Nederland in een veranderend klimaat, WL | delft hydraulics, Delft, Netherlands, 1-166, 2007.

Kok, M., Huizinga, H. J., Vrouwenvelder, A. C. W. M., and Barendregt, A.: Standaardmethode2004 - schade en slachtoffers als gevolg van overstromingen, RWS Dienst Weg- en Waterbouwkunde, 2005.

Kreibich, H., Seifert, I., Merz, B., and Thieken, A.: Development of FLEMOcs - a new model for the estimation of flood losses in the commercial sector, Hydrol. Sci. J., 55, 1302-1314, 2010.

Kron, W. and Thumerer, T.: Water-related disasters: Loss trends and possible countermeasures from a (re-)insurers point of view Germany, 2002.

Lammersen, R., Engel, H., van de Langemheen, W., and Buiteveld, H.: Impact of river training and retention measures on flood peaks along the Rhine, J. Hydrol., 267, 115-124, 2002.

Landesamt für Umwelt Baden-Württemberg: Das Hochwasser vom Oktober/November 1998 in Baden-Württemberg, in: Oberirdische Gewässer, Gewässerökologie, 65, 144 pp., 2000.

Loonen, W. and Koomen, E.: Calibration and validation of the land use scanner allocation algorithms, Netherlands Environmental Agency, Bilthoven, 2009.

Luino, F., Cirio, C., Biddoccu, M., Agangi, A., Giulietto, W., Godone, F., and Nigrelli, G.: Application of a model to the evaluation of flood damage, GeoInformatica, 13, 339-353, doi:10.1007/s10707-008-0070-3, 2009.

Maaskant, B., Jonkman, S. N., and Bouwer, L. M.: Future risk of flooding: An analysis of changes in potential loss of life in south Holland (the Netherlands), Environ. Sci. Policy, 12, 157-169, 2009.

Merz, B., Kreibich, H., Thieken, A., and Schmidtke, R.: Estimation uncertainty of direct monetary flood damage to buildings, Nat. Hazards Earth Syst. Sci., 4, 153-163, doi:10.5194/nhess-4-1532004, 2004.

Merz, B., Thieken, A. H., and Gocht, M.: Flood risk mapping at the local scale: Concepts and challenges, in: Flood risk management in Europe - innovation in policy and practice, edited by: Begum, S., Stive, M. J. F., and Hall, J. W., Advances in natural and technological hazards research, Springer, Dordrecht, Netherlands, 231-251, 2007.

Merz, B., Kreibich, H., Schwarze, R., and Thieken, A.: Review article "Assessment of economic flood damage", Nat. Hazards Earth Syst. Sci., 10, 1697-1724, doi:10.5194/nhess-10-16972010, 2010.

Messner, F., Pennning Rowsell, E. C., Green, C., Meyer, V., Tunstall, S. M., and van der Veen, A.: Evaluating flood damages: Guidance and recommendations on principles and methods, FLOODsite, Report No. T09-06-01, 2007. 
Meyer, V. and Messner, F.: National flood damage evaluation methods - a review of applied methods in England, the Netherlands, the Czech Republic and Germany, Umweltforschungszentrum Leipzig-Halle, Leipzig, Report No. 21/2005, 2005.

Middelkoop, H., Daamen, K., Gellens, D., Grabs, W., Kwadijk, J. C. J., Lang, H., Parmet, B. W. A. H., Schädler, B., Schulla, J., and Wilke, K.: Impact of climate change on hydrological regimes and water resources management in the Rhine basin, Climatic Change, 49, 105-128, 2001.

Penning-Rowsell, E. C., Johnson, C., Tunstall, S., Tapsell, S., Morris, J., Chatterton, J., and Green, C.: The benefits of flood and coastal risk management: A handbook of assessment techniques, Flood Hazard Research Centre, Middlesex University Press, 2005.

Silva, W. and Reuter, C.: Risikoanalyse für die länderübergreifenden Deichringe am Niederrhein, DeutschNiederländische Arbeitsgruppe Hochwasser, Aachen und Arnhem, 2006.

Smith, D. I.: Flood damage estimation - a review of urban stagedamage curves and loss functions, Water Sa, 20, 231-238, 1994.

Sächsische Staatskanzlei: Schadensausgleich und Wiederaufbau im Freistaat Sachsen, Dresden, 2003. te Linde, A. H., Aerts, J. C. J. H., Bakker, A. M. R., and Kwadijk, J. C. J.: Simulating low-probability peak discharges for the Rhine basin using resampled climate modeling data, Water Resour. Res., 46, W03512, doi:10.1029/2009WR007707, 2010.

te Linde, A. H., Bubeck, P., Dekkers, J. E. C., de Moel, H., and Aerts, J. C. J. H.: Future flood risk estimates along the river Rhine, Nat. Hazards Earth Syst. Sci., 11, 459-473, doi:10.5194/nhess-11-459-2011, 2011.

Thieken, A. H., Muller, M., Kreibich, H., and Merz, B.: Flood damage and influencing factors: New insights from the $\mathrm{Au}-$ gust 2002 flood in Germany, Water Resour. Res., 41, W12430, doi:10.1029/2005WR004177, 2005.

Verburg, P. H. and Overmars, K. P.: Combining top-down and bottom-up dynamics in land use modeling: Exploring the future of abandoned farmlands in Europe with the dyna-clue model, Landscape Ecol., 24, 1167-1181, 2009.

Verburg, P. H., Eickhout, B., and van Meijl, H.: A multi-scale, multi-model approach for analyzing the future dynamics of European land use, Ann. Reg. Sci., 42, 57-77, doi:10.1007/s00168007-0136-4, 2008.

Wouters, C. A. H. and Holterman, S. R.: Overstromingsrisicokaarten, HKV lijn in water, 2007. 